\title{
INFLUENCE OF SOME INTERCALATIONS ON ACTIVATION OF PRE-BAKED CLAY
}

\author{
IMTIAZ AHMAD ${ }^{a}{ }^{*}$ HAMEED ULLAH ${ }^{a, b}$ \\ a Institute of Chemical Sciences, University of Peshawar, 25120, N.W.F.P, Pakistan \\ ${ }^{b}$ Instituto de Quimica, Universidade Estadual de Campinas, 13083-970, Campinas, Sao Paulo, Brazil. \\ 'Instituto de Química, Universidad Estadual de Campinas, 13083-970, Campinas, Sao Paulo, Brazil. \\ (Received: July 23, 2008 - Accepted: May 6, 2009)
}

\begin{abstract}
We report on the influence of temperature, mixing ratio and holding time of $\mathrm{NaOH} \& \mathrm{KOH}$ intercalations on the surface area, micropore volume and micropore width of pre-baked clay samples. Pore size \& surface area analyzer was used to measure the surface area, micropore volume and average pore width using Dubinin-Radushkevich (DR) method. A meaning full effect was observed when the temperature was increased from ambient up to $150{ }^{\circ} \mathrm{C}$ in case of both intercalating agents. Increasing temperature beyond $150{ }^{\circ} \mathrm{C}$ caused a decline in surface area generation even up to $750{ }^{\circ} \mathrm{C}$. The results also show that mixing ratio has a positive effect on the porosity and the micropore surface area increases as the mixing ratio increases in case of both intercalating agents. The influence of holding time shows two different trends. In case of $\mathrm{NaOH}$, the porosity increases as the time increases while in case of $\mathrm{KOH}$, the porosity decreases as the time increases. SEM, EDX and XRD studies were also performed. The results show effective insertion of the sodium and potassium into the clay matrix thereby causing generation of porosity.
\end{abstract}

Keywords: clay; baked clay; activation; intercalation; dubinin-radushkevich (DR) method

\section{INTRODUCTION}

There is a tremendous interest in research on nanostructure materials in recent years due to their superior sportive, chemical, thermal and mechanical properties $^{1-6}$. Nanostructure materials are enjoying popularity in catalyst preparations. Moreover, they are considered as effective adsorbents for pollutants removal /sequestration. As, it is well established that surface topography and internal interface structure of the materials is known to substantially affect their bulk properties ${ }^{7}$. Therefore, there is a need to look in to these properties.

There are various approaches by which such materials can be activated. Some investigators have used different chemicals to open up the blind pores and to increase emptiness in the internal structure ${ }^{8}$. Acid leaching procedure for the porous materials activation is reported in the literature ${ }^{9}$. Some adsorbents are activated using zinc chloride as intercalation agent ${ }^{10}$. Phosphoric acid also shows good activation ability ${ }^{11}$. In addition, some researchers have reported methods other than chemical activation. Physical activation with steam to get high micropore ${ }^{12}$ and irradiating with gamma rays have been documented in the literature ${ }^{13}$. Activating clay using simultaneous chemical as well as physical activation is extensively reported ${ }^{14-16}$.

We report on the use of $\mathrm{NaOH}$ and $\mathrm{KOH}$ as intercalating agents to pre baked clay, separately. The influence of temperature, mixing ratio and holding time on porosity, micropore volume and pore width is discussed.

\section{EXPERIMENTAL}

Collection of sample

Pre-baked clay sample was collected from a local brick kiln according to the standard method of sample collection, ground, and dried in an oven at 105 ${ }^{\circ} \mathrm{C}$ in order to remove the surface moisture. The clay understudy was analyzed by electron dispersive energy scattering (EDS) technique. The EDS signature along with the composition is provided in Fig. 1.

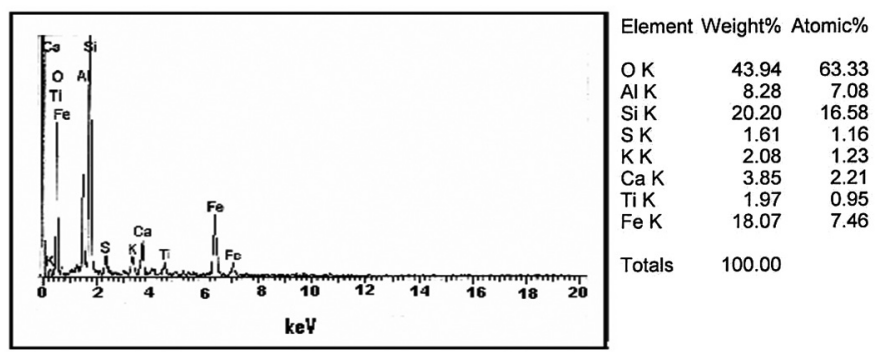

Fig. 1. EDS signature of original clay.

Solvent intercalation

Aqueous solutions of $\mathrm{NaOH}$ and $\mathrm{KOH}$ (AR grade) were prepared in desired percentages i, e $1 \%, 5 \%$ and $10 \%$. Baked clay samples were intercalated in a vat with $\mathrm{NaOH}$ and $\mathrm{KOH}$, separately while varying the temperature, mixing ratio of intercalating agents and holding time of intercalation.

\section{Effect of temperature}

For evaluating the temperature influence on surface area, micropore volume and micropore width, one g portions of baked clay sample were subjected separately to solvent intercalation using aqueous solutions of $\mathrm{NaOH}$, $\mathrm{KOH} .10 \mathrm{ml}$ aliquot of the respective solution was added to each sample and heated at $150{ }^{\circ} \mathrm{C}, 500{ }^{\circ} \mathrm{C}$ and $750{ }^{\circ} \mathrm{C}$, respectively. Each of the hydro thermally treated samples was washed with copious amount of de-ionized water, dried in a vacuum oven at $70{ }^{\circ} \mathrm{C}$ in order to remove all the surface and entrapped moisture. The prepared samples were kept in vials for determination of surface area, micropore volume and micropore width.

\section{Effect of mixing ratio}

In order to study the effect of mixing ratio on surface area, micropore volume and micropore width of the clay understudy, one $\mathrm{g}$ of sample was subjected to solvent intercalation using $\mathrm{NaOH}, \mathrm{KOH}$ prepared in concentration of $1 \%, 5 \%$ and $10 \%$, separately. Further, treatment was done in a similar fashion as described above.

\section{Effect of holding time}

For studying the time influence, one $\mathrm{g}$ of baked clay sample was subjected to same intercalations performed for time duration of $5 \mathrm{hr}, 15 \mathrm{hr}$ and $24 \mathrm{hr}$, separately. Each of the hydro thermally treated samples was washed exhaustively with deionized water till free of alkali, dried in a vacuum oven and analyzed as under.

\section{Surface area, micropore width and micropore volume analysis}

For the determination of surface area and pore volume, the whole and variously intercalated samples were analyzed using pore size and surface area analyzer Model (Quanta Chrome Nova 2200e) under the conditions reported elsewhere ${ }^{8}$. The surface area and micropore volume were calculated using Dubinin-Radushkevich Method (DR method) (drmethod) ${ }^{17}$. Average pore width was calculated using the formulae: $2 \mathrm{~V}$

Where

$\mathrm{V}$ is volume and $\mathrm{A}$ is the area of the pores

\section{SEM Analysis}

SEM micrographs of the original and variously intercalated clay samples were obtained by Scanning Electron Microscope (SEM) Model JSM 5910 JEOL Company Japan. Each of the samples was mounted on a disc and coated with gold.

\section{EDX Analysis}

Energy dispersive X-ray spectrophotometer (EDX) Model Inea 200, Made UK, company oxford was used for the analysis of original clay sample. 


\section{XRD Analysis}

X-ray diffraction (XRD) analysis of the samples was done with X-ray diffractometer (Rigaku Tokyo) using $\mathrm{Cu} \mathrm{K} \alpha$ radiation generated at $35 \mathrm{kV}, 20$ $\mathrm{mA}$. Each sample was filled in an aluminum sample holder and scanned in a step-scan mode $[0.05(\mathrm{o}) / \mathrm{step}]$ over the angular range of $8^{\circ}-30^{\circ}(2 \theta)$.

\section{RESULTS AND DISCUSSION}

Clay understudy was analyzed by EDS. The chemical composition is provided in Fig.1 which shows that the clay under trial is enriched in oxides of silicon and aluminum with calcium, potassium and titanium as minor constituents. In addition, the matrix contains iron oxide as next abundant mineral. The presence of sulfur evidents the existence of sulphides and sulphates of $\mathrm{Si}$. $\mathrm{Al}, \mathrm{Ca}, \mathrm{K}$, and $\mathrm{Ti}$ in small quantities. From the data it is affirm that the clay understudy mainly belong to smectite group of clay with general formula of $\mathrm{C}_{0.5}\left(\mathrm{Si}_{7} \mathrm{Al}_{.8} \mathrm{Fe}_{2.2}\right)\left(\mathrm{Fe}_{3.5} \mathrm{Al}_{.4} \mathrm{Mg}_{.1}\right) \mathrm{O}_{20}(\mathrm{OH})_{4}$.

The influence of parameters like temperature, mixing ratio and holding time of intercalation using $\mathrm{NaOH}$ and $\mathrm{KOH}$ on the porosity, pore volume and pore width of pre-baked clay has been evaluated

\section{Effect of temperature}

Activation of baked clay was performed at $150{ }^{\circ} \mathrm{C}, 500{ }^{\circ} \mathrm{C}$, and $750{ }^{\circ} \mathrm{C}$. The changes in surface area, micro pore volume and pore width as a function of temperature is provided in Table 1 .

Table 1. Changes in surface area, pore width, \& micropore volume as a function of intercalation temperature.

\begin{tabular}{|c|c|c|c|c|c|c|}
\hline \multirow[t]{2}{*}{$\begin{array}{c}\text { Temperature } \\
\left({ }^{\circ} \mathrm{C}\right)\end{array}$} & \multicolumn{2}{|c|}{$\begin{array}{l}\text { Surface area } \\
\left(\mathrm{m}^{2} / \mathrm{g}\right)\end{array}$} & \multicolumn{2}{|c|}{$\begin{array}{l}\text { Pore width } \\
\left(\mathrm{A}^{\circ}\right)\end{array}$} & \multicolumn{2}{|c|}{$\begin{array}{c}\text { Micropore volume } \\
(\mathrm{cc} / \mathrm{g})\end{array}$} \\
\hline & $\mathrm{NaOH}$ & $\mathrm{KOH}$ & $\mathrm{NaOH}$ & $\mathrm{KOH}$ & $\mathrm{NaOH}$ & $\mathrm{KOH}$ \\
\hline Original & 96.00 & 96.00 & 6.250 & 6.250 & 0.03 & 0.03 \\
\hline Ambient & 71.90 & 58.87 & 8.344 & 6.794 & 0.03 & 0.02 \\
\hline 150 & 140.48 & 201.68 & 7.110 & 6.941 & 0.05 & 0.07 \\
\hline 500 & 112.68 & 183.56 & 7.099 & 7.626 & 0.04 & 0.07 \\
\hline 750 & 73.92 & 52.87 & 8.116 & 7.565 & 0.03 & 0.02 \\
\hline
\end{tabular}

The surface area determined in case of $\mathrm{NaOH} \& \mathrm{KOH}$ treatments at ambient temperature was $71.90 \mathrm{~m}^{2} \mathrm{~g}^{-1}$ and $58.87 \mathrm{~m}^{2} \mathrm{~g}^{-1}$, respectively. In the next set of experiments, the temperature was increased upto $150{ }^{\circ} \mathrm{C}$. The surface area determined in case of $\mathrm{NaOH}$ was $140.48 \mathrm{~m}^{2} \mathrm{~g}^{-1}$ and in case of $\mathrm{KOH}$ was $201.68 \mathrm{~m}^{2} \mathrm{~g}^{-1}$. The temperature was further increased to $500{ }^{\circ} \mathrm{C}$. The surface area determined in case of $\mathrm{NaOH}$ was $112.68 \mathrm{~m}^{2} \mathrm{~g}^{-1}$ and in case of $\mathrm{KOH}$ was 183.86.In the next step; the temperature was further increased to $750{ }^{\circ} \mathrm{C}$. The surface area determined in case of $\mathrm{NaOH}$ was $73.92 \mathrm{~m}^{2} \mathrm{~g}^{-1}$ and in case of $\mathrm{KOH}$ was $140.48 \mathrm{~m}^{2} \mathrm{~g}^{-1}$.

From the data compiled in Tables 1, it can be seen that surface area is increased significantly when the temperature is increased from ambient to 150 ${ }^{\circ} \mathrm{C}$. The effect is more pronounced in case of $\mathrm{KOH}$ where a manifold increase in surface area is observed. The reason can be thought is heating to this level, the removal of sorbed water molecules is expedited and the significant moisture out gassing opens up the otherwise blind pores causing alterations in pores dimensions. The increase in surface area in case of both metal hydroxides also corresponds to their tunneling effect under soft hydrothermal conditions ${ }^{18}$.

The significant increase in case of potassium intercalation compared to sodium is due to the size of the inserting ion which in turn caused effective tunneling in the matrix compared to sodium which is of small size and instead of tunneling, some other structures might have generated due to poor advective and diffusive action of sodium. It is well established that the size of tunnels corresponds to the size of the templates inserted ${ }^{19}$.

It can be observed from the data assembled in Table 1 that a decline in surface area is resulted when the sample was heated up to $500{ }^{\circ} \mathrm{C}$ followed by heating up to $750^{\circ} \mathrm{C}$. This adverse effect on surface area when the temperature was increased from $150{ }^{\circ} \mathrm{C}-750{ }^{\circ} \mathrm{C}$ is attributed due the fact that increase in temperature causing the onset of decomposition of the discrete mineral inclusions in the matrix leading to formation of respective metal oxides thereby causing a decline in the surface area of the matrix ${ }^{20}$. It is also observed that both metal hydroxides caused a decrease in the surface area and this decrease in both cases is quite significant particularly at high temperature $\left(750^{\circ} \mathrm{C}\right)$. The reason can be thought is the super plastic behavior of alkali metals to form eutectics at high temperature with the already present inorganic elements in the matrix or to coagulate other elements to form clusters ${ }^{21}$ leading to clogging of pore channels.

The nitrogen adsorption isotherms of the aforementioned original and variously intercalated samples are provided in Figs 2 (a) \& 2 (b). The DR plot of the representative sample is provided in Fig. 3. All the isotherms obtained reveal hysteresis loop with a definite plateau. The major nitrogen adsorption occurs at low relative pressures indicating that the clay is porous with narrow pore size distribution. Upon comparing the isotherms obtained in case of sodium and potassium intercaltions at ambient temperature, followed by 150 ${ }^{\circ} \mathrm{C}$, followed by $500{ }^{\circ} \mathrm{C}$, followed by $750{ }^{\circ} \mathrm{C}$, it seems simple that porosity of the clay understudy was increased significantly when it was heated at $1500^{\circ} \mathrm{C}$ with either of the intercalating agents.

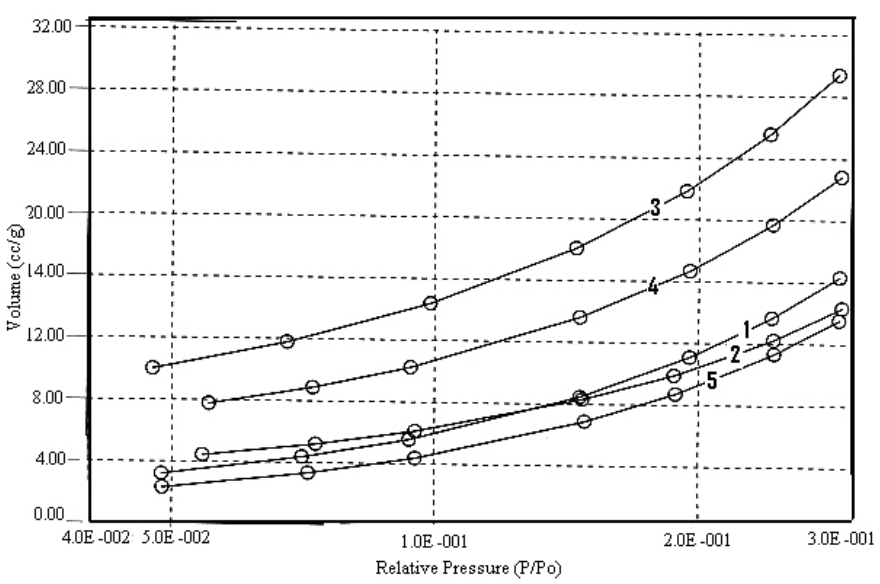

Fig. 2 (a). Nitrogen adsorption desorption isotherms of original clay and clay intercalated with $\mathrm{NaOH}$ as a function of temperature: $1=$ virgin, $2=$ room temperature, $3=150{ }^{\circ} \mathrm{C}, 4=500{ }^{\circ} \mathrm{C}, 5=750^{\circ} \mathrm{C}$.

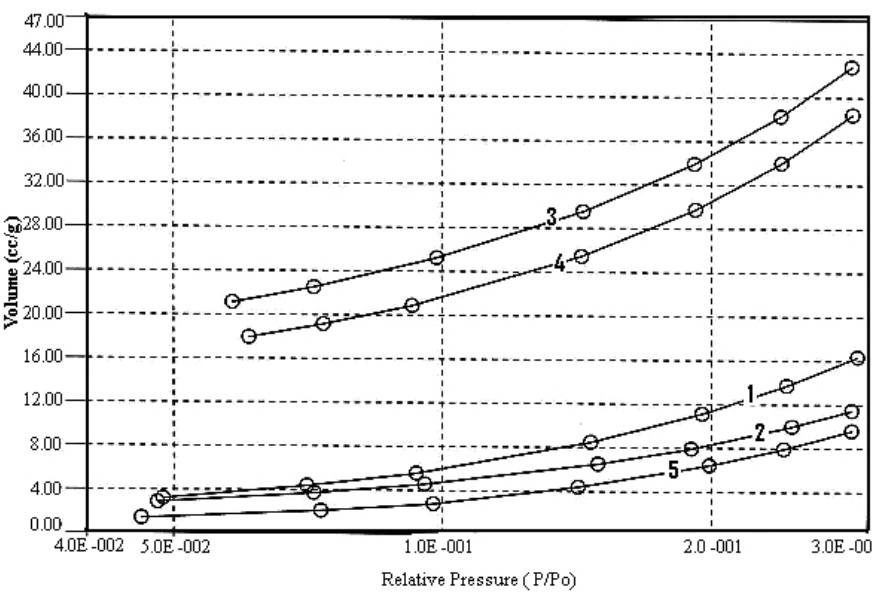

Fig. 2 (b). Nitrogen adsorption desorption isotherms of original clay and clay intercalated with $\mathrm{KOH}$ as a function of temperature: $1=$ virgin, $2=$ room temperature, $3=150{ }^{\circ} \mathrm{C}, 4=500{ }^{\circ} \mathrm{C}, 5=750{ }^{\circ} \mathrm{C}$. 


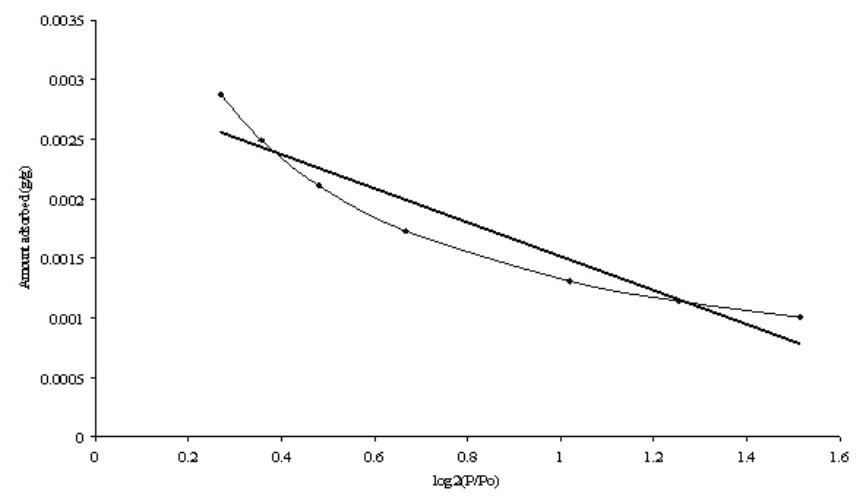

Fig. 3. Dubinin-Radushkevich plot for original clay sample.

In order to ascertain the influence of temperature on the pore width, the clay was treated separately with $\mathrm{NaOH}$ and $\mathrm{KOH}$ at ambient temperate, 150 , 500 and $750{ }^{\circ} \mathrm{C}$. The pore width determined in case of $\mathrm{NaOH}$ at ambient temperature was $8.344 \mathrm{~A}^{\circ}$ and in case of $\mathrm{KOH}$ was $6.794 \mathrm{~A}^{\circ}$. The temperature was then increased to $150{ }^{\circ} \mathrm{C}$. The pore width determined in case of $\mathrm{NaOH}$ was $7.110 \mathrm{~A}^{\circ}$ and in case of $\mathrm{KOH}$ was $6.941 \mathrm{~A}^{\circ}$. The temperature was further increased up to $500^{\circ} \mathrm{C}$. The pore width determined in case of $\mathrm{NaOH}$ was 7.099 $\mathrm{A}^{\circ}$ and in case of $\mathrm{KOH}$ was $7.626 \mathrm{~A}^{\circ}$. The temperature was next increased to $750{ }^{\circ} \mathrm{C}$ and the pore width determined in case of $\mathrm{NaOH}$ was $8.116 \mathrm{~A}^{\circ}$ and in case of $\mathrm{KOH}$ was $7.565 \mathrm{~A}^{\circ}$.

It can be seen a marginal change in average pore width when the clay was heated progressively in the presence of the aforementioned intercalating agents. This can be ascribed to the formation of tunnels and eutectics \& topotectics microstructures or directional solidification, hence leaving behind a solid with wider pores. The effect of temperature on pore widening of elutrilithe has already been reported in the literature ${ }^{22}$.

Experiments were performed in a similar fashion in order to evaluate the influence of temperature on the pore volume. The micropore volume determined at ambient temperature for $\mathrm{NaOH}$ treated clay was $0.03 \mathrm{cc} / \mathrm{g}$ and for $\mathrm{KOH}$ was $0.02 \mathrm{cc} / \mathrm{g}$. The temperature was then increased to $150^{\circ} \mathrm{C}$. The value obtained in case of $\mathrm{NaOH}$ was $0.05 \mathrm{cc} / \mathrm{g}$ and in case of $\mathrm{KOH}$ was $0.07 \mathrm{cc} / \mathrm{g}$. The temperature was next increased to $500^{\circ} \mathrm{C}$, the pore volume determined in case of $\mathrm{NaOH}$ was $0.04 \mathrm{cc} / \mathrm{g}$ and in case of $\mathrm{KOH}$ was $0.07 \mathrm{cc} / \mathrm{g}$. The temperature was further increased to $750{ }^{\circ} \mathrm{C}$. The values of pore volume were; for $\mathrm{NaOH}$, $0.03 \mathrm{cc} / \mathrm{g}$ and for $\mathrm{KOH}, 0.02 \mathrm{cc} / \mathrm{g}$. The reasons visualized for this increase in pore volume are similar as given in the case of porosity.

Effect of mixing ratio

Activation of baked clay was performed with $1 \%, 5 \%$ and $10 \%$ mixing ratios. The changes in surface area, pore volume and pore width as a function of mixing ratio are provided in Table 2 . The surface area determined at zero concentration was $53.78 \mathrm{~m}^{2} \mathrm{~g}^{-1}$. The intercalating agents were then applied to the clay in $1 \%, 5 \%$ and $10 \%$ mixing ratio. The surface area determined in case of $1 \% \mathrm{NaOH}$ was $53.12 \mathrm{~m}^{2} \mathrm{~g}^{-1}$, and in case of $\mathrm{KOH}$ was $51.90 \mathrm{~m}^{2} \mathrm{~g}^{-1}$. The ratio was then increased to $5 \%$. The surface area determined was; for $\mathrm{NaOH}, 103.84$ $\mathrm{m}^{2} \mathrm{~g}^{-1}$ and for $\mathrm{KOH}, 114.34 \mathrm{~m}^{2} \mathrm{~g}^{-1}$. The mixing ratio was further increased to $10 \%$ and the values obtained were; for $\mathrm{NaOH}, 140.48 \mathrm{~m}^{2} \mathrm{~g}^{-1}$ and for $\mathrm{KOH}$, $201.68 \mathrm{~m}^{2} \mathrm{~g}^{-1}$. The data shows that increase in mixing ratio has a positive effect on surface area generation in case of the clay understudy.

It is affirmed from the data provided in the Table 2 that surface area shows a linear increase with the increase in concentration of the metal hydroxide. This is attributed due to the fact that when we increase the concentration, the particles swell or dilatate due to the imbibition of $\mathrm{NaOH}$ and $\mathrm{KOH}$ which in turn exert pressure on the walls of the pore leading to widening and lengthening in pore dimensions. As afore mentioned, the increase in surface area corresponds mostly to tunneling ability of the metal ions understudy. Thus, increase in ion concentration leads to a more tunnel formation thereby resulting an increase in surface area ${ }^{23}$.
Table 2. Changes in surface area, pore width, \& micropore volume as a function of intercalation ratio.

\begin{tabular}{|c|c|c|c|c|c|c|}
\hline \multirow[t]{2}{*}{$\begin{array}{l}\text { Intercalation ratio } \\
(\%) \\
\end{array}$} & \multicolumn{2}{|c|}{$\begin{array}{l}\text { Surface area } \\
\left(\mathrm{m}^{2} / \mathrm{g}\right)\end{array}$} & \multicolumn{2}{|c|}{$\begin{array}{l}\text { Pore width } \\
\left(\mathrm{A}^{\circ}\right)\end{array}$} & \multicolumn{2}{|c|}{$\begin{array}{l}\text { Micropore volume } \\
\text { (cc/g) }\end{array}$} \\
\hline & $\mathrm{NaOH}$ & $\mathrm{KOH}$ & $\mathrm{NaOH}$ & $\mathrm{KOH}$ & $\mathrm{NaOH}$ & $\mathrm{KOH}$ \\
\hline 0.0 & 53.78 & 53.78 & 7.437 & 7.437 & 0.02 & 0.02 \\
\hline 1.0 & 53.12 & 51.90 & 7.530 & 7.707 & 0.02 & 0.02 \\
\hline 5.0 & 103.84 & 114.34 & 7.704 & 6.996 & 0.04 & 0.04 \\
\hline 10.0 & 140.48 & 201.68 & 7.118 & 6.941 & 0.05 & 0.07 \\
\hline
\end{tabular}

The nitrogen adsorption isotherms of the aforementioned variously intercalated samples are provided in Figs. 4 (a) \& 4 (b). The major nitrogen adsorption occurs at low relative pressures indicating that the material is porous with narrow pore size distribution. Upon comparing the isotherms obtained in case of sodium and potassium hydroxide at $0 \%, 1 \%, 5 \%$ and $10 \%$, it is evident that porosity of the clay understudy was increased significantly with the increase in concentration of both intercalating agents.

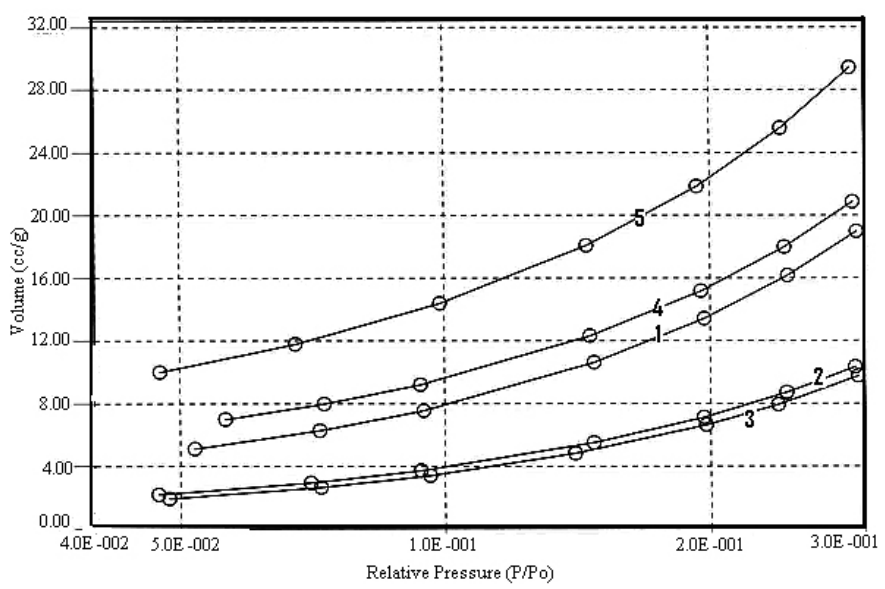

Fig. 4 (a). Nitrogen adsorption desorption isotherms of original clay and clay intercalated with $\mathrm{NaOH}$ as a function of concentration. $1=$ virgin, 2 =zero concentration, $3=1 \%, 4=5 \%, 5=10 \%$.

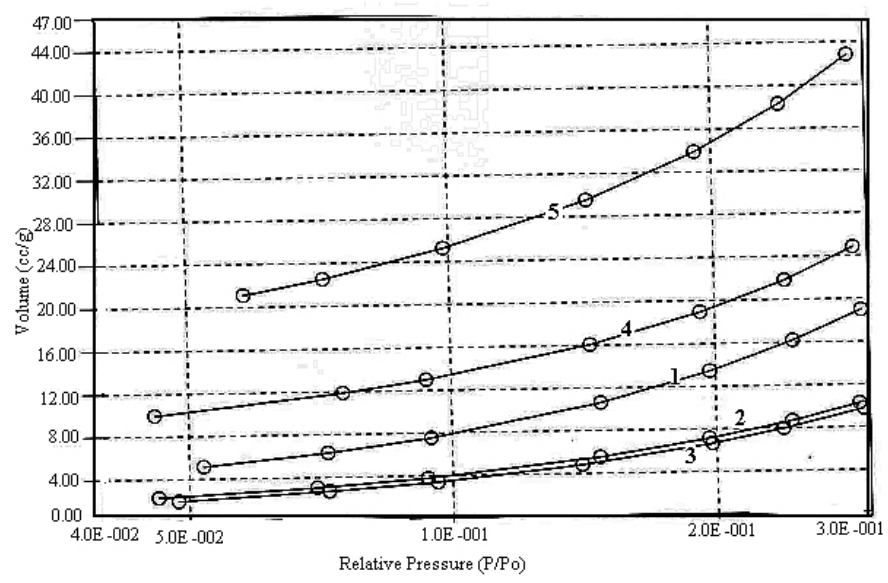

Fig.4 (b). Nitrogen adsorption desorption isotherms of original clay and clay intercalated with $\mathrm{KOH}$ as a function of concentration: $1=$ virgin, 2 =zero concentration, $3=1 \%, 4=5 \%, 5=10 \%$.

In the next step of experiments, the effect of mixing ratio on the pore width was evaluated. The increase in concentration was kept at the same frequency as above. 
The average pore width determined at zero mixing ratio was $7.437 \mathrm{~A}^{\circ}$. Incase of $1 \% \mathrm{NaOH}$, pore width determined was $7.530 \mathrm{~A}^{\circ}$, while in case of 1 $\% \mathrm{KOH}$, it was $7.707 \mathrm{~A}^{\circ}$. The mixing ratio was next increased up to $5 \%$. The value obtained in case of $5 \% \mathrm{NaOH}$ was $7.704 \mathrm{~A}^{\circ}$, and in case of $\mathrm{KOH}$ was $6.996 \mathrm{~A}^{\circ}$. The values obtained in case of $10 \% \mathrm{NaOH}$ and $\mathrm{KOH}$ were $7.118 \mathrm{~A}^{\circ}$ and $6.941 \mathrm{~A}^{\circ}$, respectively.

The micropore volume values determined at zero mixing ratio were; in case $\mathrm{NaOH}, 0.02 \mathrm{cc} / \mathrm{g}$, and in case of $\mathrm{KOH}, 0.02 \mathrm{cc} / \mathrm{g}$. Similarly, incase of 1 $\% \mathrm{NaOH}$, micropore volume determined was $0.02 \mathrm{cc} / \mathrm{g}$, while in case of $1 \%$ $\mathrm{KOH}$, it was $0.02 \mathrm{cc} / \mathrm{g}$. In case of $5 \%$ mixing ratio, the value obtained for $\mathrm{NaOH}$ was $0.04 \mathrm{cc} / \mathrm{g}$, and for $\mathrm{KOH}$ was $0.04 \mathrm{cc} / \mathrm{g}$. For $10 \% \mathrm{NaOH}$ and $\mathrm{KOH}$, the micropore volumes determined were $0.05 \mathrm{cc} / \mathrm{g}$ and $0.07 \mathrm{cc} / \mathrm{g}$, respectively.

The overall effect of metal hydroxide concentration on the pore properties can be ascribed to the efficient etching resulting in more pores formation followed by copious washing of the residual minerals and/or sodium/potassium with deionized water from the matrix ${ }^{24}$. The removal of silicon cations owing to the alkaline cations is reported elsewhere ${ }^{25}$. The other reason can be thought is the concentration of $\mathrm{OH}$ ions which in turn regulates the $\mathrm{pH}$ during solvent intercalation. The concentration of $\mathrm{OH}$ ions in turn relates to the concentration of the intercalating agent. The effect of solution $\mathrm{pH}$ on the porosity is well established ${ }^{26,27}$.

\section{Effect of holding time}

Baked clay was subjected to activation for time duration of $5 \mathrm{hr}, 15 \mathrm{hr}$ and $24 \mathrm{hr}$. The changes in pore properties as a function of holding time are provided in Tables 3. The surface area determined at zero time in case of $\mathrm{NaOH}$ was $96.00 \mathrm{~m}^{2} \mathrm{~g}^{-1}$ and in case of $\mathrm{KOH}$ was $96.00 \mathrm{~m}^{2} \mathrm{~g}^{-1}$. The time was then increased to $5 \mathrm{hr}$. The value obtained in case of $\mathrm{NaOH}$ was $111.31 \mathrm{~m}^{2} \mathrm{~g}^{-1}$, and in case of $\mathrm{KOH}$ was $201.28 \mathrm{~m}^{2} \mathrm{~g}^{-1}$. The time was then extended up to $15 \mathrm{hr}$. The value noted in case of $\mathrm{NaOH}$ was $114.74 \mathrm{~m}^{2} \mathrm{~g}^{-1}$, and in case of $\mathrm{KOH}$ was $131.00 \mathrm{~m}^{2} \mathrm{~g}$ ${ }^{1}$. The time was further extended to $24 \mathrm{hr}$. The value obtained in case of $\mathrm{NaOH}$ was $140.48 \mathrm{~m}^{2} \mathrm{~g}^{-1}$, and for $\mathrm{KOH}$ treated sample was $129.60 \mathrm{~m}^{2} \mathrm{~g}^{-1}$.

Table 3. Changes in surface area, pore width, \& micropore volume as a function of holding time.

\begin{tabular}{|c|c|c|c|c|c|c|}
\hline \multirow[t]{2}{*}{$\begin{array}{l}\text { Holding Time } \\
\text { (hrs) }\end{array}$} & \multicolumn{2}{|c|}{$\begin{array}{l}\text { Surface area } \\
\qquad\left(\mathrm{m}^{2} / \mathrm{g}\right)\end{array}$} & \multicolumn{2}{|c|}{$\begin{array}{c}\text { Pore width } \\
\left(\mathrm{A}^{\circ}\right)\end{array}$} & \multicolumn{2}{|c|}{$\begin{array}{c}\text { micropore volum } \\
(\mathrm{cc} / \mathrm{g})\end{array}$} \\
\hline & $\mathrm{NaOH}$ & $\mathrm{KOH}$ & $\mathrm{NaOH}$ & $\mathrm{KOH}$ & $\mathrm{NaOH}$ & $\mathrm{KOH}$ \\
\hline 0.0 & 96.00 & 96.00 & 6.250 & 6.250 & 0.03 & 0.03 \\
\hline 5.0 & 111.31 & 201.28 & 7.181 & 6.955 & 0.03 & 0.03 \\
\hline 15 & 114.74 & 131.00 & 6.972 & 7.633 & 0.04 & 0.07 \\
\hline 24 & 140.48 & 129.60 & 7.188 & 7.716 & 0.04 & 0.05 \\
\hline
\end{tabular}

It is evident from the data that the time shows a positive effect on the surface area in case of $\mathrm{NaOH}$ while incase of $\mathrm{KOH}$, the extension in time shows adverse effect.

The nitrogen adsorption isotherms of the aforementioned original and variously intercalated samples are provided in Figs. 5 (a) \& 5 (b). All the isotherms obtained reveal hysteresis loop with a definite plateau. The major nitrogen adsorption occurs at low relative pressures indicating that the material is porous with narrow pore size distribution. Upon comparing the isotherms obtained in case of sodium and potassium intercalations undertaken for $0 \mathrm{hr}$, followed by $1 \mathrm{hr}$, followed by $15 \mathrm{hr}$, followed by $24 \mathrm{hr}$, it is evident that porosity of the clay understudy was increased significantly when the intercalation was performed for $24 \mathrm{hr}$ in case of sodium while in case of potassium, $5 \mathrm{hr}$ caused significant improvement in porosity. Time extension beyond $5 \mathrm{hr}$ gave a rather un impressive effect.

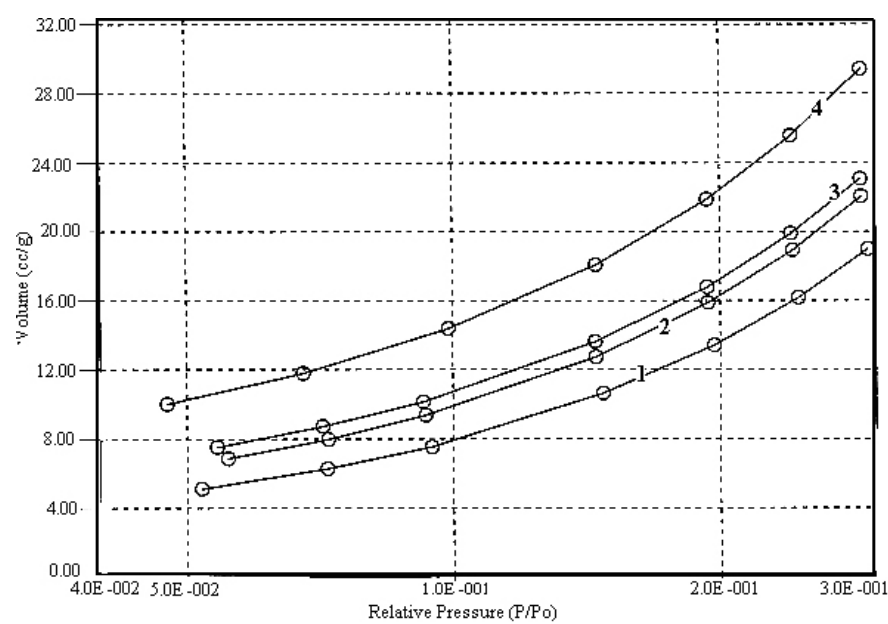

Fig. 5 (a). Nitrogen adsorption desorption isotherms of original clay and clay intercalated with $\mathrm{NaOH}$ as a function of holding time. $1=$ Virgin and Zero time, $2=5 \mathrm{hr}, 3=15 \mathrm{hr}, 4=24 \mathrm{hr}$.

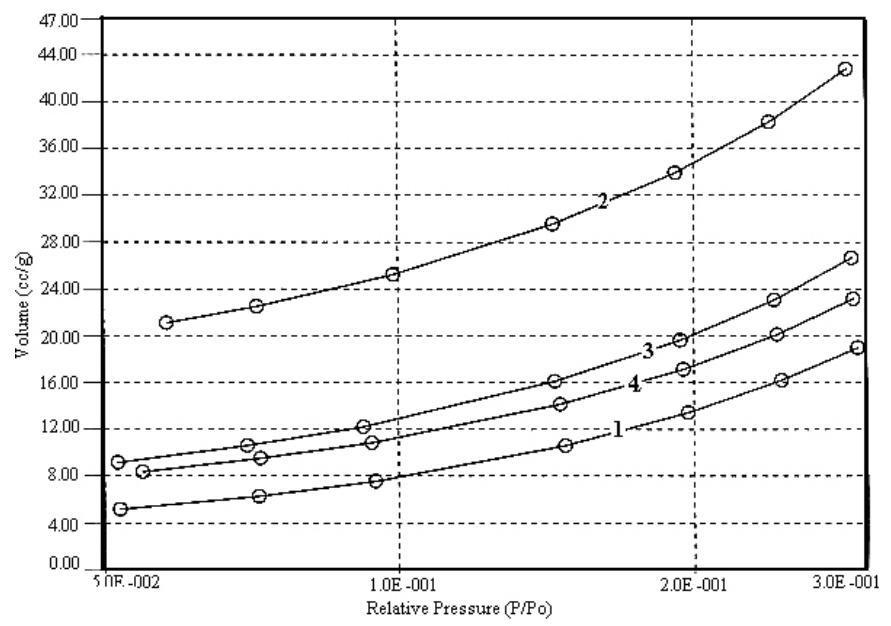

Fig. 5 (b). Nitrogen adsorption desorption isotherms of original clay and clay intercalated with $\mathrm{KOH}$ as a function of holding time: $1=$ virgin and zero time, $2=5 \mathrm{hr}, 3=15 \mathrm{hr}, 4=24 \mathrm{hr}$.

To evaluate the influence of time on the pore width, experiments were performed with the same intercalating agents used in the mixing ratio mentioned as above. The average pore width determined at zero time in case $\mathrm{NaOH}$ was $6.250 \mathrm{~A}^{\circ}$, and in case of $\mathrm{KOH}$ was $6.250 \mathrm{~A}^{\circ}$. The value obtained in case of 5 hr intercalation with $\mathrm{NaOH}$ was $7.181 \mathrm{~A}^{\circ}$, while in case of $\mathrm{KOH}$ was $6.955 \mathrm{~A}^{\circ}$. The value determined in case of $15 \mathrm{hr}$ intercalation with $\mathrm{NaOH}$ was $6.972 \mathrm{~A}^{\circ}$, and with $\mathrm{KOH}$ was $7.633 \mathrm{~A}^{\circ}$. Upon extending time up to $24 \mathrm{hr}$, the values obtained were; for $\mathrm{NaOH}, 7.188 \mathrm{~A}^{\circ}$ and for $\mathrm{KOH}, 7.716 \mathrm{~A}^{\circ}$, respectively.

The influence of time was also studied on the micropore volume determined. The values determined at zero time were; in case $\mathrm{NaOH}, 0.03$ $\mathrm{cc} / \mathrm{g}$, and in case of $\mathrm{KOH}, 0.03 \mathrm{cc} / \mathrm{g}$. In case of $5 \mathrm{hr}$ holding time, the values were: for $\mathrm{NaOH}, 0.04 \mathrm{cc} / \mathrm{g}$ and for $\mathrm{KOH}, 0.07 \mathrm{cc} / \mathrm{g}$. In case of $15 \mathrm{hr}$ holding time, the values obtained were; for $\mathrm{NaOH} 0.04 \mathrm{cc} / \mathrm{g}$, for $\mathrm{KOH}, 0.05 \mathrm{cc} / \mathrm{g}$ and in case of $24 \mathrm{hr}$ holding time, the values obtained were; $\mathrm{NaOH}, 0.05 \mathrm{cc} / \mathrm{g}$ and $\mathrm{KOH}, 0.05 \mathrm{cc} / \mathrm{g}$.

There are several reasons to endorse the above mentioned findings. The holding time usually has a positive effect on porosity generation which in turn relates to the effective leaching of the other inorganic elements by the respective leachan ${ }^{28,29}$. This lead to alteration in surface morphology, modification in crystal structures and interlayer spacing. The positive effect of holding time in case of sodium hydroxide is attributed due to the fact that increasing holding time ensures effective hydration, and hence imbibition of intercalating solution in to the micropores of the clay understudy which in turn caused porosity generation. The effect in case of potassium hydroxide intercalation, however, 
shows a reverse trend. This in turn relates to the solubility of the metal ion which is a function of molecular weight. The potassium ion is larger than the sodium ion, hence potassium ion is partially hydrolyzed in water compared to sodium at $150{ }^{\circ} \mathrm{C}$. This poor solubility might have caused poor imbibition in to the matrix upon prolonged holding time. Another reason might be the accumulation of larger potassium ions around the pore mouths, thereby clogging the pores entrances and hence inhibiting the solvent intercalation process.

\section{SEM study}

Scanning electron microscopic study of the original clay and clay intercalated separately with $\mathrm{NaOH} \& \mathrm{KOH}$ at $150{ }^{\circ} \mathrm{C}$ was performed. The corresponding SEM micrographs are provided in Fig. 6. In case of original sample, the surface roughness can be seen in the form of kernels, notches, slots and kerfs which evident that the clay understudy is porous. The SEM of clay intercalated with $\mathrm{NaOH}$ at $150{ }^{\circ} \mathrm{C}$ shows generation of pores drilled in to the matrix. The SEM of $\mathrm{KOH}$ intercalated sample picturing more roughness and valley shaped formations. Pores drilled in to the matrix are numerous in the form of black spots. Thus, it is established that $\mathrm{KOH}$ was more effectively inserted in to the clay matrix, hence generating significant porosity.
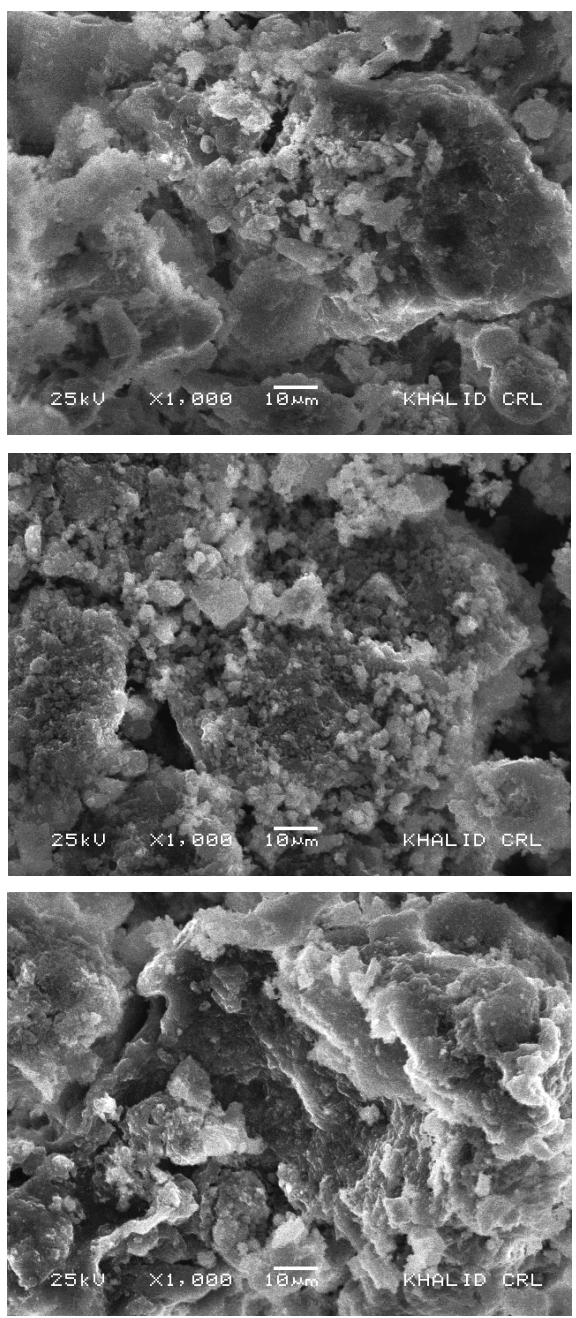

Fig. 6. SEM micrographs of original and variously intercalated clay samples (a) original (b) clay intercalated with $\mathrm{NaOH}$ at $150{ }^{\circ} \mathrm{C}$ (c) clay intercalated with $\mathrm{KOH}$ at $150^{\circ} \mathrm{C}$.

\section{XRD study}

As afore mentioned, the porosity was considerably increased in case of $\mathrm{NaOH} \& \mathrm{KOH}$ intercalations performed at a temperature of $150{ }^{\circ} \mathrm{C}$ compared to intercalations performed at $500 \& 750{ }^{\circ} \mathrm{C}$. To establish any changes in the composition of original clay and upon intercalations with $\mathrm{NaOH} \& \mathrm{KOH}, \mathrm{XRD}$ study of selected samples was performed.
The XRD pattern of original clay is provided in Fig. 7 (a). A very intense and sharp peak can be seen at $2 \Theta=12.1^{\circ}$ with d-spacing of $7.31 \AA$. The XRD pattern of $\mathrm{NaOH}$ intercalated sample is provided in Fig.7 (b). It can be seen that peak appearing in the original clay sample is slightly shifted and now appearing at $2 \Theta=11.9^{\circ}$ with d-spacing of $7.46 \AA$.

The data show a shift in the $2 \Theta$ value from $12.1^{\circ}$ to $11.9^{\circ}$ with a slight increase in the d spacing value from 7.31 to $7.46 \AA$. This increase in the d value corresponds to increase in the interlayer spacing indicating that sodium was effectively inserted in to the clay matrix

The XRD pattern of $\mathrm{KOH}$ intercalated sample is provided in Fig 7 (c). It can be seen that peak appearing in the original clay sample is now appearing at $2 \Theta=13.7^{\circ}$ with d-spacing of $13.65 \AA$ Á.
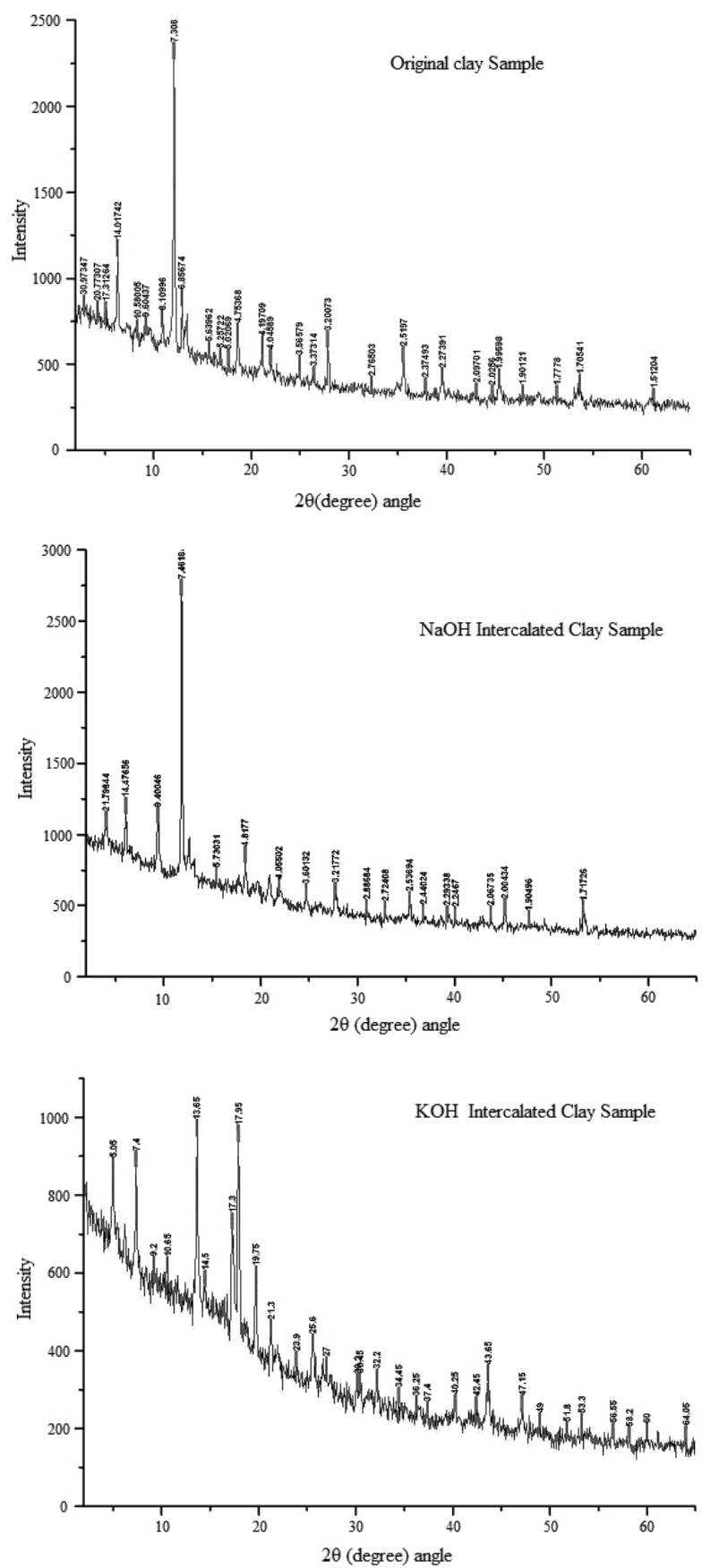

Fig. 7. XRD patterns of original and variously intercalated clay samples (a) original clay (b) clay intercalated with $\mathrm{NaOH}$ at $150^{\circ} \mathrm{C}$ (c) clay intercalated with $\mathrm{KOH}$ at $150^{\circ} \mathrm{C}$. 
The XRD pattern of $\mathrm{KOH}$ intercalated clay sample show very prominent shift in the $2 \Theta$ value from $12.1^{\circ}$ to $13.7^{\circ}$ with pronounced increase in the $\mathrm{d}$ value from 7.31 to $13.65 \AA$. From this increase, it is inferred that $\mathrm{KOH}$ is more effectively inserted as compared to $\mathrm{NaOH}$, thereby causing significant generation in porosity.

\section{CONCLUSIONS}

Surface area of the pre-baked clay was increased significantly when the sample was treated hydro thermally at $150{ }^{\circ} \mathrm{C}$. The increase was quite appreciable in case of potassium hydroxide compared to sodium hydroxide as intercalating agent. .Increasing temperature beyond $150^{\circ} \mathrm{C}$ showed an adverse effect on surface properties.

The effect of mixing ratio was meaningful. An increase in surface area was noticed while increasing the mixing ratio in case of both intercalating agents.

The influence of holding time was meaningful in case of sodium hydroxide. Increase in holding time beyond $5 \mathrm{hr}$, showed deleterious effect in case of potassium hydroxide.

\section{ACKNOWLEDGEMENTS}

The author is thankful to both TWAS and CNPQ for PhD fellowship to the scholar at UNICAMP, Sao Paulo, Brazil.

The authors are also thankful to Prof.Dr. Mohammad Riaz, Mohammad Omer and Mr. Hazart Amin, Centralized Resource Laboratory, Department of Physics, University of Peshawar, for providing laboratory facilities of Pore Size \& Surface Area Analysis, SEM and EDS.

Thanks are due to Dr. Irshad Ahmad, Associate Professor, NCE in Geology, University of Peshawar for XRD analysis.

\section{REFERENCES}

1. G.Michael, L.Robert, J. Xinqiao, J BIOMAT SCI-POLYM E. 18, 241, (2007).

2. E. Ruiz-Hitzky, The Chemical Record. 3, 88, (2003).

3. D.L. Leslie-Pelecky, Chem. Mater. 8,1770, (1996).

4. H. Chen, X. Zhou, C. Ding, J EUR CERAM SOC. 23, 1449 (2003).

5. Y.C. Zhu, K. Yukimurab, C.X. Dingc, P.Y. Zhang, Thin Solid Films. 388, 277, (2001).

6. B.H. Kear, L.E. McCandlish, NANOSTRUCT MATER. 3, 19, (1993).

7. H. Assender, V. Bliznyuk, K. Porfyrakis, Science. 297, 973, (2002).
8. I.Ahmad, M. Shakirullah, M. Ishaq, M.A. Khan, M. Omer, H. Ullah, J.Chil.Chem.Soc. 52,1088, (2002).

9. K. Okada, N. Nakazawa, Y. Kameshima, A. Yasumori, J. Temuujin, K.J.D. Mackenzie, M.E. Smith, CLAY CLAY MINER. 50, 624, (2002).

10. Z. Hu, E.F. Vansant, J COLLOID INTERF SCI, 176, 422, (1995).

11. S. Ichcho, E. Khouya, A. Abourriche, M. Ezzine, H. Hannache, R. Naslain, R. Pailler, J. Phys. IV France. 123, 81, (2005).

12. M.N. Alaya, M.A. Hourieh, A.M. Youssef, F. El-Sejariah, ADSORPT SCI TECHNOL. 18, 27, (2000).

13. Y.V. Pokonova, CHEM TECH FUELS OIL+. 37, 368, (2001).

14. C.E. Seng, C.G. Lee1, K.Y. Liew, J AM OIL CHEM SOC, 78, 831, (2001).

15. S. Banerjee, V.R. Choudhary, P INDIAN AS-CHEM SCI, 112, 535 , (2000).

16. W.T. Tsai, H.P. Chen, M.F. Hsieh, H.F. Sun, C.W. Lai, J ENVIRON SCI HEAL A. 38, 685, (2003).

17. F.C. Garcia, J. Paredes, A.M. Alonsoand, J.M.D. Tascon, J MATER CHEM, 2002,12, 3213, (2002)

18. Q. Feng, T. Horiuchi, L. Liu, K. Yanagisawa, T. Mitsushio, CHEM LETT. 29, 284, (2000)

19. Q. Feng, K. Yanagisawaand, N.Yamasaki, J POROUS MAT. 5,153, (1998).

20. F. M. Labajos, V. Rives, M.A. Ulibarri, J MATER SCI . 27, 1546, (1992).

21. A. Ataie, M. R. Piramoon, I. R. Harris, C. B.Ponton, J MATER SCI, 30, 5600, (1995).

22. H.U. Zhonghua, E.F. Vansant, Carbon, 33, 1293, (1995).

23. Q. Feng, K. Yanagisawaand, N.Yamasaki, CHEM COMMUN.1607, (1996).

24. A. Ahmadpour, D. D. Do, Carbon. 34, 471, (1996).

25. W.T. Tsai, K.J. Hsien, C.W. Lai, IND ENG CHEM RES. 43, 7513, (2004).

26. O. Altin, H.O. Özbelge, T. Dogu J COLLOID INTERF SCI, 217,19, (1999).

27. N.D. Hutson, M.J. Hoekstra, R.T. Yang, MICROPOR MESOPOR MAT, 28, 447, (1999).

28. K. Okada, N. Nakazawa, Y. Kameshima, A. Yasumori, J. Temuujin, K. J. D. Mackenzie, M.E. Smith, CLAY CLAY MINER, 50, 624, (2002).

29. W. T. Wofford, P.C. Dell'Orco, E.F. Gloyna, J CHEM ENG DATA. 40, 968, (1995). 